\title{
Three new records of deep-sea squat lobsters of the genus Munidopsis Whiteaves from the southwestern Atlantic Ocean (Decapoda: Galatheidae)
}

Marcos Tavares and Priscila Campinho

\begin{abstract}
Munidopsis nitida (A. Milne-Edwards, 1880) and Munidopsis sigsbei (A. Milne-Edwards, 1880), previously known from the West Indies and Gulf of Mexico, are recorded for the first time from the southwestern Atlantic (southeastern Brazil). Munidopsis erinacea (A. Milne-Edwards, 1880), known from West Indies, Gulf of Mexico, and from off northeastern Brazil, is recorded for the first time from the southwestern Atlantic. The Brazilian material is herein compared with specimens from the Caribbean Sea and Gulf of Mexico.
\end{abstract}

\section{Introduction}

Ongoing studies on deep-sea decapods and stomatopods from off the Brazilian coast have revealed the presence of several new species and records from the southwestern Atlantic (Manning et al., 1989; Tavares 1991a; 1991b; 1996a; 1996b; 1997a; Tavares \& Albuquerque, 1990; Tavares \& Mendonça Jr., 1997). In this account, two deep-sea squat lobsters previously known from the West Indies and Gulf of Mexico are recorded for the first time from off southeastern Brazil, Munidopsis nitida (A. Milne-Edwards, 1880) and Munidopsis sigsbei (A. MilneEdwards, 1880). Munidopsis erinacea (A. Milne-Edwards, 1880), known from West Indies, Gulf of Mexico, and from off northeastern Brazil, is recorded for the first time from the southwestern Atlantic. Opportunity is taken herein to elaborate on the taxonomy of these three species.

The descriptions are based upon the specimens from the southwestern Atlantic. Abbreviations used includs: BM, Natural History Museum (British Museum), London; MNHN, Muséum national d'Histoire naturelle, Paris; USNM, National Museum of Natural History, Smithsonian Institution, Washington; USU, Coleção Carcinolgica da Universidade Santa Úrsula, Rio de Janeiro; Mxp3, third maxilliped; P1, cheliped; P2-5, pereiopods 1 to 5; St, station; CB, Blake trawl; CP, beam trawl, cl, carapace length measured from the tip of the rostrum to the posterior margin of the carapace; $\mathrm{m}$, meters; $\mathrm{mm}$, millimeters; fms, fathoms.

\section{Munidopsis erinacea}

(A. Milne-Edwards, 1880)

(Figs. 1, 2)

Galathodes erinaceus A. Milne-Edwards, 1880: 53

Munidopsis erinacea.- A. Milne-Edwards \& Bouvier, 1894: 225, 275 [key]; 1897: 67 [redescription], pl. VII, fig. 9-12; Faxon: 1895: 89; Benedict, 1902: 277 [key], 320 [synonymy]; Doflein \& Balss, 1913: 175 [species list], 177 [distribution and depth range]; Boone, 1927: 60; Chace, 1942: 71, 74 [key], 90 [synonymy]; Pequegnat \& Pequegnat, 1970: 140 [key], 146 [synonymy]; Pequegnat et al., 1971: 5; 8 [species list]; Takeda, 1983: 93 [redescription], fig. not numbered.

Munidopsis erinaceus.- Pequegnat \& Pequegnat, 1971: 6 [key].

Material examined.- Brazil: off Per- 
nambuco, "Challenger", st. 122, 1.9.1873, $630 \mathrm{~m}$ (350 fms): 1 male, cl. $13 \mathrm{~mm}$, and 1 ovigerous female, cl. $14 \mathrm{~mm}$ (BM); TAAF MD55 1987, "Marion Dufresne", st. 41, CP07, 10.5.1987, $21^{\circ} 31^{\prime} \mathrm{S}-40^{\circ} 07^{\prime} \mathrm{W}, 750-$ 785 m: 1 male (USU); idem: st. 42, CB76, 27.5.1987, $18^{\circ} 58^{\prime} \mathrm{S}-37^{\circ} 49^{\prime} \mathrm{W}, 600-637 \mathrm{~m}$ : 4 males and 3 females, one of which ovigerous (USU), 1 males and 1 female (MNHN); idem: st. 64, CB105, 2.6.1987, $23^{\circ} 46^{\prime} \mathrm{S}-42^{\circ} 09^{\prime} \mathrm{W}, 592-610 \mathrm{~m}$ : 2 females (USU); idem: st. 65, CB106, 2.6.1987, $23^{\circ} 54^{\prime} \mathrm{S}-42^{\circ} 10^{\prime} \mathrm{W}, 830 \mathrm{~m}$ : 1 young male (USU).

Comparative material: Caribbean Sea: "Alaminos", st. 70-A-10-31, 1970, 720 m (400 fms): 1 male and 2 females (USNM 154403); Dominica, off Crompton Point: “Oregon", st. 5928, 4.3.1966, $15^{\circ} 38^{\prime} \mathrm{N}-$ $61^{\circ} 12^{\prime} \mathrm{W}, 576 \mathrm{~m}$ (320 fms): 4 males and 2 females, one of which ovigerous (USNM 169570).

Diagnosis. - The following are additions to the previously published data. Carapace moderately arched transversely; dorsal surface covered with rather long and sparse hairs; cervical groove well distinct, conspicuous shallow transverse depression in anterior part of cardiac region. Rostrum trispinose, slightly curved upwards, narrow, lateral margin with one acute spine of each side directed obliquely forward, tip exceeding eyestalks by about two times their length. Anterolateral angle with a sharp spine curved inward. Gastric region strongly inflated; anterior gastric region bearing one pair of sharp spines, and posterior to each another less developed pair of spines; remainder of gastric region smooth. Anterior branchial region moderately inflated bearing one strong spine. Posterior branchial region less inflated than the anterior branchial region bearing two spines, anterior stronger than posterior; cardiac region strongly inflated, armed with two pairs of sharp spines, anteriors stronger than posteriors. Posterior margin adorned with tiny tubercles. Lateral plate with

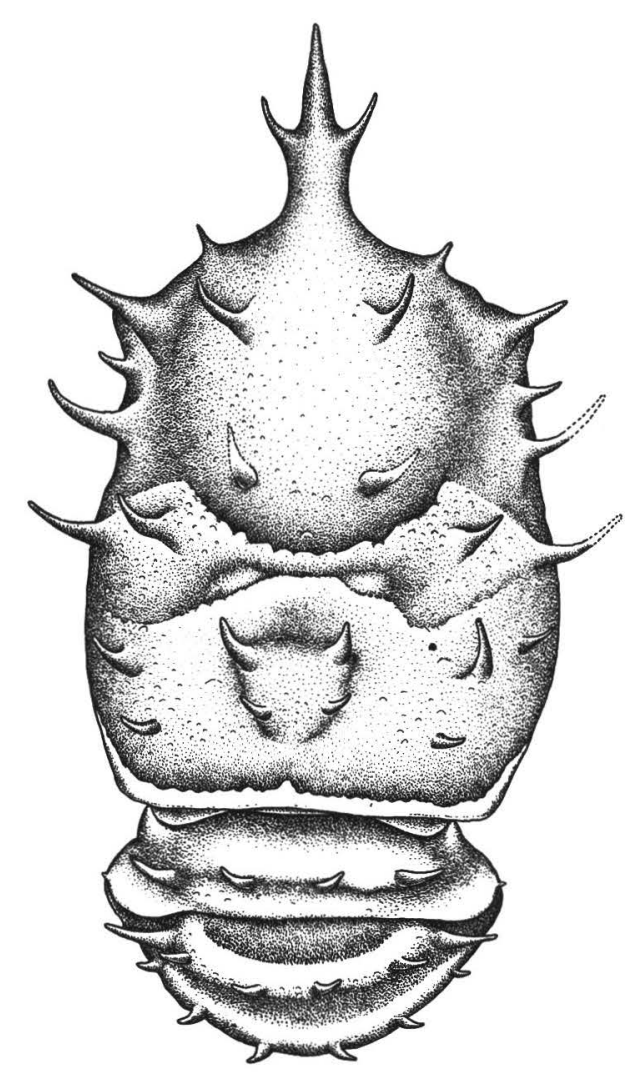

Fig. 1. Munidopsis erinacea (A. Milne-Edwards, 1880), dorsal view. Brazil: TAAF MD55 1987, "Marion Dufresne", st. 41, CP07, 21 $31^{\prime}$ 'S$40^{\circ} 07^{\circ} \mathrm{W}, 750-785 \mathrm{~m}$ : male cl. $21 \mathrm{~mm}$ (USU).

longitudinal rugae, projecting anteriorly below antennal peduncle; angular anterior tip rounded. First abdominal somite, very narrow, unarmed; somite 2 armed with transverse row of four sharp spines, abdominal pleura ending in sharp spine; somites 3-4 armed with transverse row of six sharp spines, only abdominal pleura of somite 3 end in sharp spines; somite 5-6 unarmed. Telson divided into 8 plates. Epipods absent from chelipeds and all walking legs. Branchial formula: Mxp3 (1 epipod; 2 arthrobranch); P1 (2 arthrobranch); P2-P4 (2 arthrobranch; 1 pleurobranch); P5 (1 pleurobranch).

Variations.- Two types of trispinose rostrum can be recognized in the speci- 


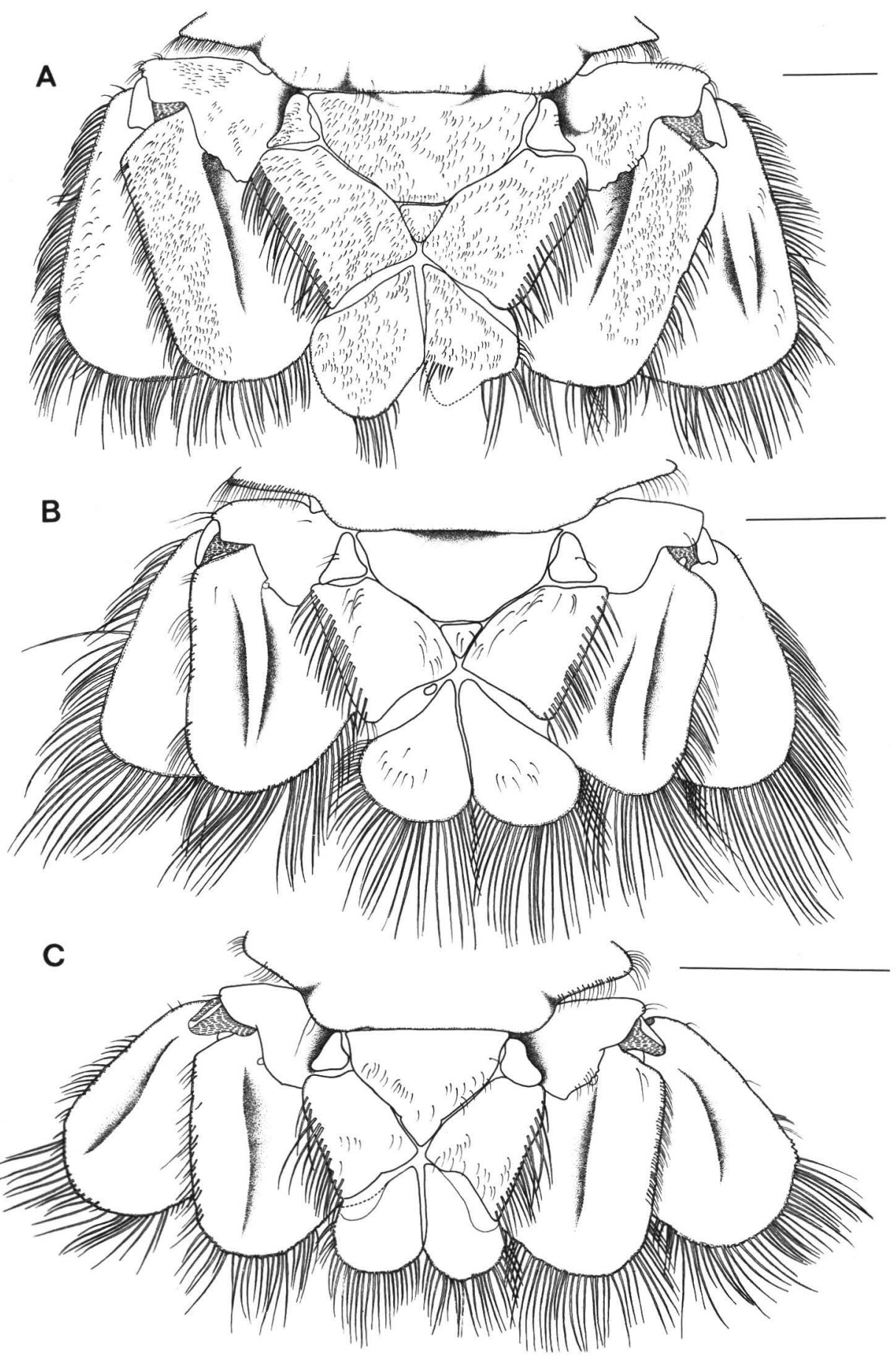

Fig. 2. Munidopsis erinacea (A. Milne-Edwards, 1880). A-C, tail fan. A, C. Brazil: TAAF MD55 1987, "Marion Dufresne”, st. 42, CB76, $18^{\circ} 58^{\prime} \mathrm{S}-37^{\circ} 49^{\circ} \mathrm{W}, 600-637 \mathrm{~m}$ : males (USU); B. Dominica: “Oregon", st. $5928,1^{\circ} 38^{\prime} \mathrm{N}-61^{\circ} 12^{\prime} \mathrm{W}, 576 \mathrm{~m}$ : male (USNM 169570). Scales: A-C, $2 \mathrm{~mm}$. 
mens examined: (1) with lateral rostral spines more closely aligned with the median spine; (2) with lateral rostral spines more divergent. Whereas in the Caribbean region both rostral types are present, all the southwestern Atlantic specimens fall into the second type so far.

The chelipeds are sexually dimorphic. Those of adult males are stronger and present an accentuated gap between the dactylus and propodus, while the chelipeds of adult and young females as well as young males resemble each other (see also A. Milne-Edwards \& Bouvier, 1894: 225). Variation in the number and development of spines on the posterobranchial region of the carapace, chelipeds and pereiopods occurs frequently and have no relation with the sex of the individuals. We found the following note by Boone (1927: 60) surprising: "It is interesting to note that each of the five specimens at hand are ornamented with the exact number of spines and spinules identically distributed as is possessed by the specimen figured by Prof. Milne-Edwards [probably A. Milne-Edwards \& Bouvier, 1897: pl. VII, fig. 9-12, as A. Milne-Edwards, 1880 provides no illustration at all].

Boone (1927: 60) noticed that body pilosity varies with age of the specimens: "The largest male [cl $18 \mathrm{~mm}$ ] is also covered with a much more conspicuous fur than are the younger specimens".

In males and females the abdominal pleura of somites 2-3 typically end in a distinct sharp spine. However in a female from the southwestern Atlantic the abdominal pleura of somite 4 also end in a sharp spine, while in a male from the same area only the abdominal pleura of somite 2 end in a spine. Typically, $M$. erinacea has eight telson plates (fig. 2AB), however in a parasitized adult male from the southwestern Atlantic the central telson plate did not differentiate (fig. $2 C)$. The male and female from off Pernambuco (Brazil) examined by Henderson (1888: 149) have eight telson plates instead of the seven depicted by him (pl. XVI, fig. 4).

Distribution.- West Indies (Sombrero, Culebra, Frederickstadt, St. Croix, Nervis, Martinique, St. Lucia, St. Vincent, off Glover Reef), Gulf of Mexico, British Honduras, and Brazil (Pernambuco and off southeastern Brazilian coast), from 271 to 1197 meters depth.

\section{Munidopsis nitida}

\section{(A. Milne-Edwards, 1880)}

(Figs. 3, 4)

Orophorhynchus nitidus A. Milne-Edwards, 1880: 59.

Munidopsis nitida.- A. Milne-Edwards \& Bouvier, 1894: 275 [key], 278; 1897: 74 [synonymy] (pl. VI, fig. 6-7), 75-77; Faxon, 1895: 84; Benedict, 1902: 276 [key], 323 [synonymy]; Doflein \& Balss, 1913: 176 [species list]; Chace, 1942: 73 [key]; Pequegnat \& Pequegnat, 1970: 139 [key], 153 [synonymy], fig. 5-12; 1971: 6 [key]; Pequegnat et al., 1971: 5, 8 [species list]; Ambler, 1980: 19-20; Williams \& Van Dover, 1983: 487; Williams \& Turner, 1986: 617, 619-622; Williams \& Baba, 1989: 902 (fig. 2h), 907; Van Dover \& Williams, 1991: 146, 150.

Munidopsis nitidus.- Doflein \& Balss, 1913: 177 [geographical distribution and depth range].

Orophorhynchus spinosus A. Milne-Edwards, 1880: 58.

Orophorhynchus spinosus [within the synonymy of $M$. nitida].- A. Milne-Edwards \& Bouvier, 1897: 74-75; Benedict, 1902: 323; Pequegnat \& Pequegnat, 1970: 153.

Material examined.- Brazil: TAAF MD55 1987, “Marion Dufresne”, st. 39, CP68, 26.5.1987, $18^{\circ} 55^{\prime} \mathrm{S}-37^{\circ} 49^{\prime} \mathrm{W}, 1200$ $\mathrm{m}: 1$ male (USU).

Comparative material: Bahamas: " $\mathrm{R} / \mathrm{V}$

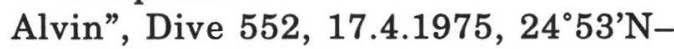
$77^{\circ} 40^{\prime} \mathrm{W}, 2042 \mathrm{~m}$ : 2 males, 8 females, 1 juvenile, A. B. Williams det. (USNM 231340); idem: Dive $754,11.5 .1977,24^{\circ} 53^{\prime} \mathrm{N}-77^{\circ} 40^{\circ} \mathrm{W}$, $2066 \mathrm{~m}$ : 1 male, 1 female, A. B. Williams det. (USNM 231348).

Diagnosis. - The following are additions to the previously published data. 

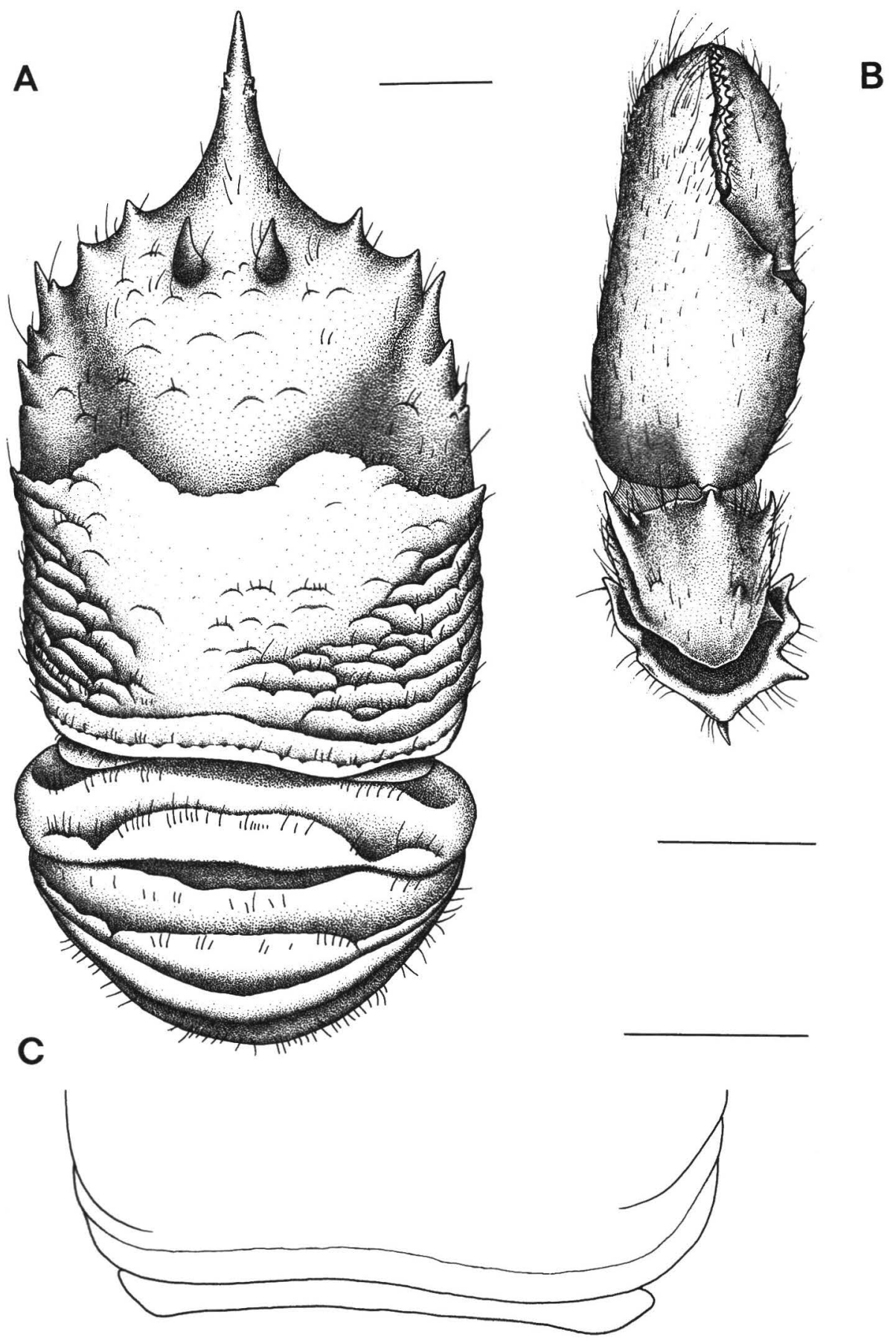

Fig. 3. Munidopsis nitida (A. Milne-Edwards, 1880). A-C, Brazil: TAAF MD55 1987, "Marion Dufresne", st. $39, \mathrm{CP} 68,18^{\circ} 55^{\prime} \mathrm{S}-37^{\circ} 49^{\circ} \mathrm{W}, 1200 \mathrm{~m}$ : adult male, cl $25 \mathrm{~mm}$ (USU). A, dorsal view; B. external view of the left cheliped; $\mathrm{C}$, schematic representation of the posterior region of the carapace in dorsal view. Scales: A-C, $4 \mathrm{~mm}$. 

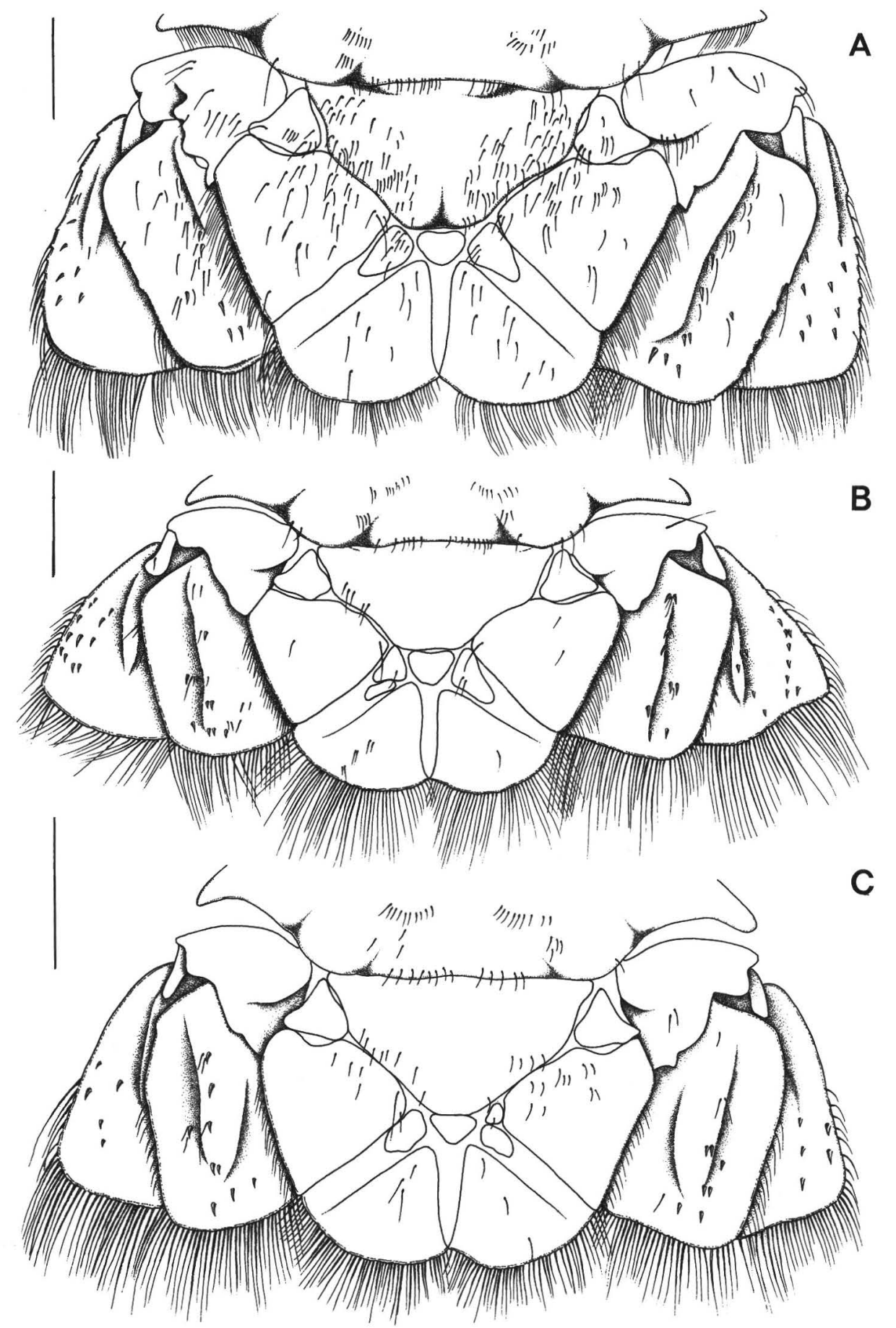

Fig. 4. Munidopsis nitida (A. Milne-Edwards, 1880). A-C, tail fan. A. Brazil: TAAF MD55 1987, "Marion Dufresne", st. 39, CP68, $18^{\circ} 55^{\prime} \mathrm{S}-37^{\circ} 49^{\circ} \mathrm{W}, 1200 \mathrm{~m}$ : male (USU); B-C. Bahamas: "R/V Alvin”, Dive $552,24^{\circ} 53^{\prime} \mathrm{N}-77^{\circ} 40^{\prime} \mathrm{W}, 2042 \mathrm{~m}$ : male and female respectively (USNM 231340 ). 


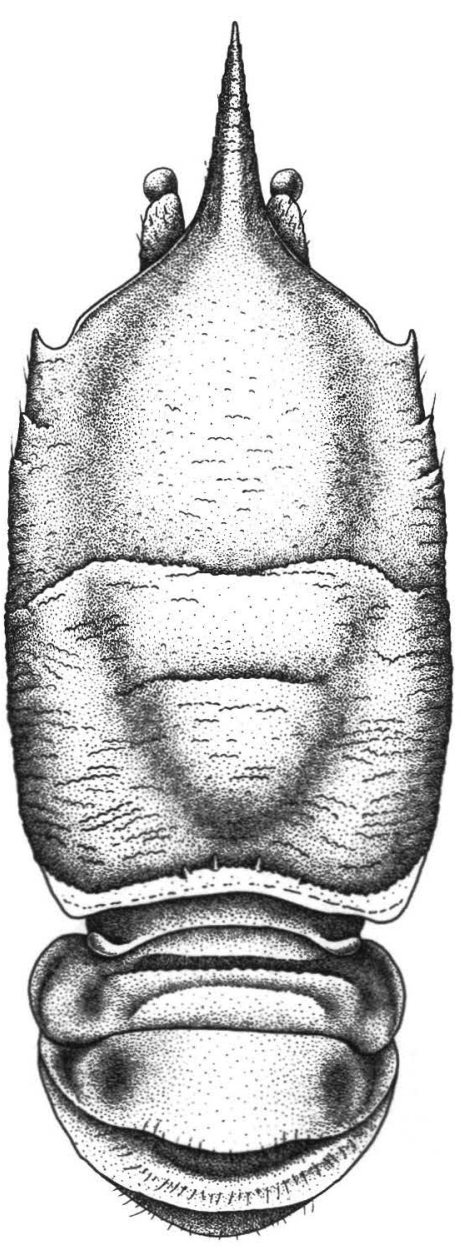

Fig. 5. Munidopsis sigsbei (A. Milne-Edwards, 1880), dorsal view. Brazil: TAAF MD55 1987, "Marion Dufresne", st. 43, CB77, 1900'S$37^{\circ} 47^{\prime} \mathrm{W}, 900-790 \mathrm{~m}$ : female cl $24 \mathrm{~mm}$ (USU).

Carapace moderately arched transversely; cervical groove rather distinct. Rostrum slightly curved upwards, narrow, lateral margin irregularly serrate with minute tubercles, tip exceeding eyestalks by about three times their length (eye spines excluded), no dorsal carina. Anterolateral angle a small tooth. Gastric region moderately inflated; anterior gastric region bearing one pair of acute spines directed forward, remainder of gastric region with short transverse ridges of granules. Anterior branchial region bearing strong anterolateral spine followed by moderate acute spine and scattered small tubercles. Remainder of carapace with short transverse ridges of granules. Posterior margin preceded by narrow raised ridge with tiny tubercles. Lateral plate ornamented as carapace, projecting anteriorly below antennal peduncle; angular anterior tip bearing distinct small acute tubercle. Abdominal somites unarmed; transverse ridge of segments $2-3$ smooth, divided into anterior and posterior parts by concave trough, that of segments 4 obsolescent; segments 5 and 6 smooth. End of abdominal pleura of somites 2-6 rounded. Telson divided into 10 plates. Epipod well developed on chelipeds, absent on all walking legs. Branchial formula: Mxp3 (1 epipod; 2 arthrobranch); P1 (2 arthrobranch); P2-P4 (2 arthrobranch; 1 pleurobranch); P5 (1 pleurobranch).

Variations. - The granules on the dorsal surface of the carapace vary with age, that is, large individuals tend to present more granules than small ones. A. Milne-Edwards \& Bouvier (1897: 74) considered two eye spines as characteristic of $M$. nitida; Benedict (1902: 276) and Chace (1942: 73) used the eye spines as a key character for $M$. nitida. It is worth noting that two specimens out of the fourteen examined herein present an additional eye spine.

Remarks.- Galacantha spinosa, Orophorhynchus spinosus and $O$. nitidus were described by A. Milne-Edwards (1880). Later on, the genera Galacantha and Orophorhynchus merged into the synonymy of Munidopsis Whiteaves, 1874 (see A. Milne-Edwards \& Bouvier, 1897; Chace, 1942: 69-72; Baba, 1988: 138). G. spinosa, $O$. spinosus and $O$. nitidus were transferred to Munidopsis accordingly.

A. Milne-Edwards \& Bouvier (1897: 74-75) found that $O$. spinosus was a junior synonym of $O$. nitidus (ICZN, 1985: $24((\mathrm{a}, \mathrm{b}))$. Despite its rejection as a valid name, Orophorhynchus spinosus A. Milne-Edwards, 1880, remains available 
(ICZN, 1985: 10 (g)). Once Galacantha and Orophorhynchus fell into the synonymy of Munidopsis, the invalid name Orophorhynchus spinosus A. Milne-Edwards, 1880 , became a threaten to the valid name Galacantha spinosa A. MilneEdwards, 1880. We submit, therefore, that Orophorhynchus spinosus A. MilneEdwards, 1880, junior synonym of $O$. nitidus, be considered here a junior homonym of the valid name Galacantha spinosa A. Milne-Edwards, 1880.

Distribution.-West Indies: Bahamas, Guadeloupe and Dominica; Gulf of Mexico; southeastern Brazil; from 1350 to $2149 \mathrm{~m}$.

A. Milne-Edwards \& Bouvier (1897: 74) attributed to $M$. nitida a record of Munidopsis brevimana Henderson, 1885, from the Arrou Islands and from between Papua and the Admiralty Islands (see Henderson, 1885: 414; 1888: 155; Williams \& Turner, 1986: 621). Actually that record should, instead, be attributed to Munidopsis ciliata Wood-Mason, 1891 (see Faxon, 1895: 84; Baba, 1988: 147).

\section{Munidopsis sigsbei \\ (A. Milne-Edwards, 1880)}

(Figs.5-8)

Galathodes Sigsbei A. Milne-Edwards, 1880: 56.

Munidopsis sigsbei.- Henderson, 1888: 150 [redescription], pl. XVIII, fig. 2; A. MilneEdwards \& Bouvier, 1894: 213, fig. 17, 214, fig. 18 , 219, fig. 22 , 225, fig. 29, 244, fig. 31 , 275 [key], 278; Benedict, 1902: 276 [key], 326 [synonymy]; Chace, 1942: 73 [key], 82 [distribution]; 1956: 15; Pequegnat \& Pequegnat, 1970: 129 [depth range], 139 [key], 156 [synonymy]; 1971: 5 [key]; Pequegnat et al. 1971: 5 [depth range], 8 [list of species]; Takeda, 1983: 95 [redescription], fig. not numbered; Van Dover \& Williams, 1991: 146 [list of species].

Munidopsis Sigsbei.- A. Milne-Edwards \& Bouvier, 1897: 65-66, 83 [redescription] pl. V fig. 8-26, 89-91.

Munidopsis Sigsbeyi [sic].-Doflein \& Balss, 1913: 176 [list of species], 178 [distribution and depth range].

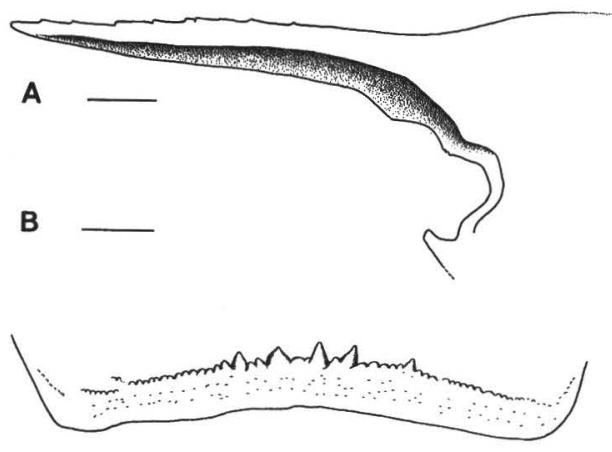

Fig. 6. Munidopsis sigsbei (A. Milne-Edwards, 1880). A-B, West Indies: "Challenger", st. 23, off Sombrero, $810 \mathrm{~m}$ : female (BM). A. lateral view of the rostrum; B. Schematic representation of the posterior margin of the carapace in dorsal view. Scales: A-B, $1 \mathrm{~mm}$.

Material examined.- Brazil: TAAF MD55 1987, "Marion Dufresne", st. 43, CB77, 27.5.1987, $19^{\circ} 00^{\prime} \mathrm{S}-37^{\circ} 47^{\prime} \mathrm{W}, 900-$ $790 \mathrm{~m}$ : 1 female cl $24 \mathrm{~mm}$ (USU).

Comparative material: West Indies: "Blake", st. 29, $1877-1878,24^{\circ} 86^{\top} \mathrm{N}-84^{\circ} 05^{\top} \mathrm{W}$, $1719 \mathrm{~m}(955 \mathrm{fms}): 1$ male cl. $21 \mathrm{~mm}, 1$ female cl. $17 \mathrm{~mm}$ (MNHN-Ga 290); "Challenger", st. 23, 15.3.1873, off Sombrero, $810 \mathrm{~m}$ (450 fms): 1 female cl. $20 \mathrm{~mm}$ (BM).

Diagnosis. - The following are additions to the previously published data. Carapace deeply arched transversely; cervical groove poorly excavated. Rostrum directed upwards, narrow, serration on lateral margin inconspicuous, tip exceeding eyestalks by about two times their length, dorsal carina weakly developed, bearing obsolescent tiny tubercles. Anterolateral angle a sharp small spine. Gastric region strongly inflated, adorned with sparse ridges of granules oriented transverse. Transverse ridges of granules developing progressively towards posterior margin of carapace. Posterior margin preceded by wide raised ridge with tiny tubercles, armed with three acute teeth. Lateral plate ornamented as carapace, projecting anteriorly below antennal 

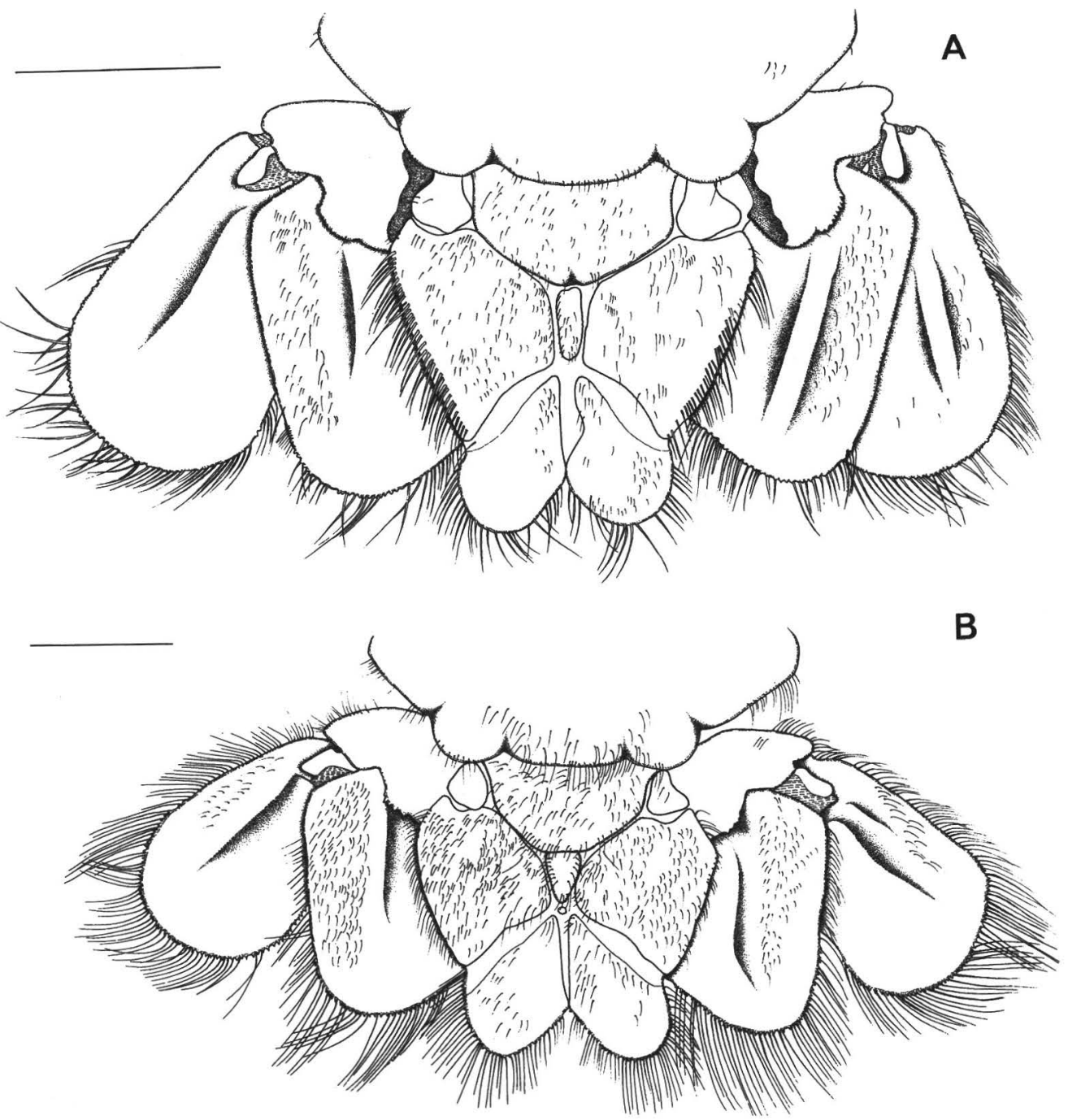

Fig. 7. Munidopsis sigsbei (A. Milne-Edwards, 1880). A-B, tail fan. A. West Indies: "Blake", st. 29, $24^{\circ} 86^{\prime} \mathrm{N}-84^{\circ} 05^{\prime} \mathrm{W}, 1719 \mathrm{~m}$ : male (MNHN-Ga 290); B. Brazil: TAAF MD55 1987, "Marion Dufresne”, st. $43, \mathrm{CB} 77,1^{\circ} 00^{\prime} \mathrm{S}-37^{\circ} 47^{\prime} \mathrm{W}, 900-790 \mathrm{~m}$ : female (USU). Scales: A-B, $3 \mathrm{~mm}$.

peduncle; angular anterior tip rounded. Abdominal somites unarmed; transverse ridge of segment 2 strong, smooth, diminishing progressively from that of segment 3 to 6 . End of abdominal pleura of somites 2-6 rounded. Telson divided into 8 plates. Epipods on chelipeds only. Branchial formula: Mxp3 (2 arthrobranch; 1 pleurobranch); P1 (2 arthrobranch); P2-P4 (2 arthrobranch; 1 pleurobranch); P5 (1 pleurobranch).

Variations.- The examined specimens from the Caribbean and southwestern Atlantic show only minor variations in relation to one another. Most of that variation refers to the number and development of teeth and spines on the carapace and appendages. Typically, the posterior 

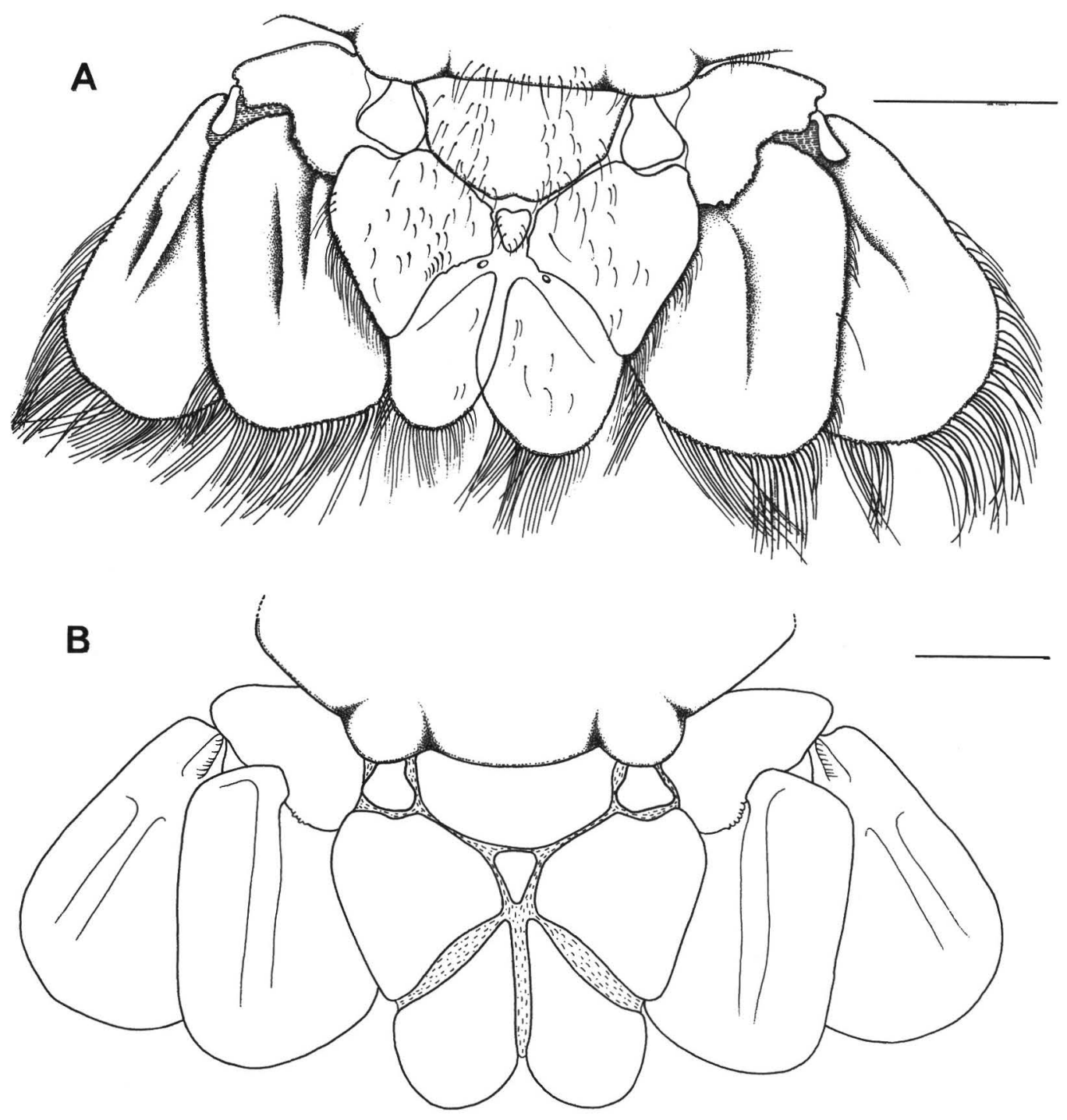

Fig. 8. Munidopsis sigsbei (A. Milne-Edwards, 1880). A-B, tail fan. A. West Indies: "Blake", st. $29,24^{\circ} 86^{\prime} \mathrm{N}-84^{\circ} 05^{\prime} \mathrm{W}, 1719 \mathrm{~m}$ : female (MNHN-Ga 290); B. Idem: "Challenger", st. 23, off Sombrero, $810 \mathrm{~m}$ : female (BM). Scales: A-B, $2 \mathrm{~mm}$.

margin of the carapace has a row of low tubercles armed with three acute teeth (see A. Milne-Edwards, 1880: 56), whose size varies from specimen to specimen (fig. 9), however the female BM from the Caribbean Sea presents two additional teeth on the posterior margin of the carapace (fig. 6B, see also Henderson, 1888: pl. XVIII, fig.2); serration on the posterior dorsal margin of the peduncle of the uropods is less pronounced in the BM female (fig. 8B); spinulation on the meri of the chelipeds varies within the same specimen (e.g., male MNHN-Ga 290); in female MNHN-Ga 290 the carpus and merus of the third left pereiopod present the antero-distal spines well developed, while in male MNHN-Ga 290 those spines 
are very low; the chelipeds are sexually dimorphic being also stronger in males than in females (see also A. Milne-Edwards \& Bouvier, 1894: 225; 1897: 88).

Remarks. - The figure provided by Henderson (1888: pl. XVIII, fig. 2) has two inaccuracies, as it omits a small spine lateral to the eyestalk and depicts seven telson plates instead of eight (figs. 7A-B, 8A-B). According to Pequegnat et al. (1971: 5) M. sigsbei "is the most common of the deep-water Munidopsis in the Gulf [of Mexico], followed by M. simplex".

Distribution.- Caribbean Sea: Frederickstadt, Guadeloupe, Martinique, off Sombrero, Cuba, south of Jamaica, Saint Croix, Grenada; Gulf of Mexico and Yucatan Bank; northwestern coast of South America; and southeastern Brazil; from 640 to 1755 meters depth.

\section{Acknowledgments}

Early stages of this paper were done while MT held a one-month appointment as "Maître de Conférence" at the Muséum national d'Histoire naturelle, Paris. Thanks to Danièle Guinot for facilitating this visit and support while there. We are sincerely grateful to Keiji Baba (Kumamoto University, Japan) and Austin B. Williams (National Marine Fisheries Service, Smithsonian Institution, Washington) for reviewing a draft of the manuscript (Austin also kindly checked the English text); to Lipke B. Holthuis (Nationaal Natuurhistorisch Museum) for his advise concerning the nomenclatural questions; to Paul F. Clark (The Natural History Museum, London), Nguyen Ngoc-Ho (Muséum national d'Histoire naturelle, Paris) and Austin B. Williams for the loan of specimens from their institutions; to Maria Helena Pinheiro (Santa Ursula University, Rio de Janeiro) for preparing the drawings. MT thanks J. M. Ramos (Chancellor of the Santa Ursula University, Rio de Janeiro) and A. Guille (Director of the Observatoire Océano- logique de Banyuls-sur-mer, Laboratoire Arago) for their invitation to participate in the cruise of the "Marion Dufresne" to Brazil, and CNPq (National Council for the Development of Science and Technology, Brasilia) for support in the form of ongoing grant 30.09.15/97-7.

\section{Literature Cited}

Ambler, J. W., 1980. Species of Munidopsis (Crustacea, Galatheidae) occurring off Oregon and in adjacent waters. Fishery Bulletin, 78 (1): 13-34.

Baba, K., 1988. Chirostylidae and Galatheidae Crustaceans (Decapoda: Anomura) of the "Albatross" Philippine Expedition, 19071910. Researches on Crustacea, Special Number 2: iii +203 pp.

Benedict, J. E., 1902. Description of a new genus and forty-six new species of crustaceans of the family Galatheidae, with a list of the known marine species. Proceedings of the United States National Museum, 26(1311): 243-334.

Boone L., 1927. Scientific results of the first oceanographic expedition of the "Pawnee", 1925. Crustacea from tropical east American seas. Bulletin Bingham Oceanographic Collection, 1(2): 1-147.

Chace F. A., Jr., 1942. Reports on the scientific results of the Atlantis expeditions to the West Indies, under the joint auspices of the University of Havana and Harvard University. The anomuran Crustacea. I. Galatheidea. Torreia, 11: 1-106.

Doflein F., \& Balss H., 1913. Die Galatheiden der Deutschen Tiefsee-Expedition. Wissenschaftliche Ergebnisse der Deutschen Tiefsee-Expedition auf dem Dampfer "Valvidia" 1898-1899, Jena, 20: 125-184.

Faxon W., 1895. Reports on an exploration off the west coasts of Mexico, Central and South America, and off the Galapagos Islands, in charge of Alexander Agassiz by the U.S. Fish Commission steamer "Albatross", during 1891, Lieut.-Commander Z. L. Tanner, U. S. N., commanding XV. The stalk-eyed Crustacea. Memoirs of the Museum of Comparative Zoology, 18: 1292.

Henderson J. R., 1885. Diagnoses of the new species of Galatheidea collected during the "Challenger" Expedition. Annals and Magazine of Natural History (5) 16 (96): 407-421. 
1888. Report on the Anomura collected by H.M.S. "Challenger"during the years 1873-76. "Challenger" Expedition, 187276. Report on the Scientific Results of the Voyage of H. M. S. "Challenger" during the years 1873-76. Zoology, 27 (69): i-xi, 1221.

ICNZ, 1985. (International Commission of Zoological Nomenclature). International Code of Zoological Nomenclature. Third Edition. Adopted by the XX General Assembly of the International Union of Biological Sciences. International Trust for Zoological Nomenclature, in association with the British Museum (Natural History), London: $338 \mathrm{pp}$.

Manning, R. B., Tavares, M., \& Albuquerque, E. F., 1989. Chaceon ramosae, a new deepwater crab from off Brazil (Crustacea: Decapoda: Geryonidae). Proceedings of the Biological Society of Washington, 102(3): 646-650.

Milne-Edwards, A., 1880. Reports on the results of dredging, under the supervision of Alexander Agassiz, in the Gulf of Mexico, and in the Caribbean Sea, 1877, '78, '79, by the U.S. Coast Survey steamer "Blake", Lieut.-Commander C. D. Sigsbee, U.S.N., and Commander J. R. Bartlett, U.S.N., Commanding. VIII. Études préliminaires sur les Crustacés. Bulletin of the Museum of Comparative Zoology, at Harvard College, 8(1): 1-68.

$\longrightarrow$, \& Bouvier E. L., 1894. Considérations générales sur la famille des Galathéidés. Annales des Sciences Naturelles, Zoologie (7) 16: 191-327.

, 1897. Reports on the results of dredging under the supervision of Alexander Agassiz in the Gulf of Mexico (1877-78) in the Caribbean Sea (1878-79) and along the Atlantic coast of the United States (1880) by the U.S. Coast Survey steamer "Blake", Lieut.-Commander J. R. Bartlett, U. S. N., Commanding. XXXV. Description des Crustacés de la famille des Galathéidés recueillis pendant l'expédition. Memoirs of the Museum of Comparative Zoology, at Harvard College, 19(2): 1-141.

Pequegnat L. H., \& Pequegnat W. E., 1970. Deep-sea anomurans of superfamily Galatheoidea with descriptions of three new species. In: W. E. Pequegnat \& F. A. Chace, Jr., (eds), Texas A\&M University Oceanographic Studies, Contributions on the biology of the Gulf of Mexico, 1: 125170.

,$- \&-, 1971$. New species and new records of Munidopsis (Decapoda: Galatheidae) from the Gulf of Mexico and Caribbean Sea. Texas A\&M University Oceanographic Studies, Contributions on the Biology of the Gulf of Mexico, 1 (supplement): 1-24.

$\longrightarrow, \longrightarrow$, Firth Jr., R., James, B. M., \& Roberts, T. W., 1971. Anomuran Decapoda of the superfamily Galatheoidea and family Lithodidae. In: Serial Atlas of the Marine Environment, Folio 20. Gulf of Mexico Deep-sea Fauna. Decapoda and Euphausiacea. American Geographical Society: 5-8, fig. 5; pl. 1-2, map A-D.

Takeda M., 1983. Crustaceans. In: Crustaceans and mollusks trawled off Suriname and French Guiana. Japan Marine Fishery Resource Research Center: 19-177.

Tavares, M., 1991a. Espèces nouvelles de Cyclodorippoidea Ortmann et remarques sur les genres Tymolus Stimpson et Cyclodorippe A. Milne-Edwards (Crustacea, Decapoda, Brachyura). Bulletin du Muséum national d'Histoire naturelle, Paris, 12(3-4): 623-648.

, 1991b. Redéfinition des genres Rochinia A. Milne-Edwards, Sphenocarcinus A. Milne-Edwards et Oxypleurodon Miers, et établissement du genre Nasutocarcinus gen. nov. (Crustacea, Brachyura, Majidae). Bulletin du Muséum national d'Histoire naturelle, Paris, 12(1-2): 159-179.

- , 1996a. Révision systématique des Cyclodorippoidea américains (Crustacea, Decapoda, Brachyura). Bulletin du Muséum national d'Histoire naturelle, Paris, 18(1-2): 233-295.

- 1996b. Sur la validité de Bathyplax typhlus oculiferus Miers, 1886 (Decapoda, Brachyura). Crustaceana, 69(3): 413-423.

,- 1997 . Scyllarus ramosae, new species, from the Brazilian continental slope, with notes on congeners occurring in the area (Decapoda: Scyllaridae). Journal of Crustacean Biology, 17(4): 716-724.

- \& Albuquerque, E. F., 1990. Paralomis formosa Henderson, 1888 from off southeastern Brazilian coast (Crustacea, Decapoda, Lithodidae). Boletim do Museu Nacional, 340: 1-4.

$\longrightarrow$, \& Mendonça, Jr., 1997. Bathysquilla microps (Manning, 1961), a deep-sea mantis shrimp new to the Brazilian fauna (Crustacea: Stomatopoda: Bathysquillidae). Bulletin of Marine Science, 61(3): 929-933.

Van Dover C. L., \& Williams A. B., 1991. Egg size in squat lobsters (Galatheoidea): Constraint and freedom. In: A. Wenner \& 
A. Kuris (eds.), Crustacean egg production. Crustacean Issues, 7: 143-156.

Williams, A. B., \& Baba, K., 1989. New squat lobsters (Galatheidae) from the Pacific ocean: Mariana Back Arc Basin, east Pacific Rise, and Cascadia Basin. Fishery Bulletin, 87: 899-910.

Williams A. B., \& Turner R. D., 1986. Squat lobsters (Galatheidae: Munidopsis) associated with mesh-enclosed wood panels submerged in the deep sea. Journal of Crustacean Biology, 6(3): 617-624.
Williams A. B., \& Van Dover C. L., 1983. A new species of Munidopsis from submarine thermal vents of the east Pacific Rise at $21^{\circ} \mathrm{N}$ (Anomura: Galatheidae). Proceedings of the Biological Society of Washington, 96(3): 481-488.

Address: Universidade Santa Úrsula, ICBA, Rio de Janeiro 22231-040, Brazil.

E-mail: (MT) mtavares@ax.apc.org 